\title{
ANALISIS BIAYA RELEVAN DALAM PENGAMBILAN KEPUTUSAN MENERIMA ATAU MENOLAK PESANAN KHUSUS PADA CV. MANGUNI PERKASA
}

\author{
Gabriel Michele Margaretha Raap \\ David P.E Saerang \\ Rudy J. Pusung \\ Fakultas Ekonomi dan Bisnis Jurusan Akuntansi \\ Universitas Sam Ratulangi Manado \\ email : michelle_biie@yahoo.com
}

\begin{abstract}
ABSTRAK
Keberhasilan suatu perusahaan tergantung pada kemampuan manajemen perusahaan dalam menjalankan operasi perusahaan. Pengambilan keputusan merupakan salah satu fungsi manajer. Dalam menjalankan kegiatan suatu perusahaan, maka seringkali manajemen dihadapkan pada beberapa pilihan atau alternatif dari aktivitas yang dilakukan. Untuk memilih salah satu dari alternatif tersebut, maka pihak manajemen membutuhkan informasi tentang biaya. Adapun tujuan dari penelitian ini adalah untuk mengetahui perhitungan biaya harga pokok produksi yang digunakan oleh perusahaan, serta menganalisis biaya relevan dalam kaitannya menerima atau menolak pesanan khusus. Metode yang digunakan dalam penelitian ini adalah metode deskriptif. Berdasarkan hasil penelitian, menunjukkan bahwa CV. Manguni Perkasa belum menerapkan metode analisis biaya relevan dalam menghitung harga pokok produksi. Dengan harga pesanan khusus Rp 183.600.000 mungkin akan terlihat dapat merugikan perusahaan yang pada dasarnya menjual rumah panggung dengan harga normal Rp 216.000.000, tetapi bila dianalisis kembali dengan menggunakan perhitungan metode biaya relevan sebagai cara untuk menghitung biaya variabel secara terpisah dari harga pokok produksi dengan menggunakan metode full costing, maka pesanan khusus rumah panggung dengan harga jual Rp 183.600.000 dapat diterima. Karena harga jual pesanan khusus lebih besar daripada biaya variabel yang dikeluarkan oleh perusahaan dalam memproduksi rumah panggung.

Kata Kunci: biaya relevan, biaya variabel, full costing
\end{abstract}

\begin{abstract}
The success of an enterprise depends on the ability of corporate management in running the company. Decision making is one of the functions of a manager. In carrying out the activities of a company, the management is often faced with several options or alternatives of activities undertaken. To choose one of these alternatives the management need information about costs. The purpose of this study was to determine the cost of production cost calculations used by the company, as well as analyzes of relevant costs in relation to accept or reject a special order. The method used in this research is descriptive method. Based on the results of the study, showed that CV. Manguni Perkasa not applying relevant cost analysis method in calculating the cost of production. With the price of $R p 183.6$ million special orders may be seen to be detrimental to the company that basically sells the house on stilts with the normal price of Rp 216 million, but when analyzed again using the relevant cost calculation method as a way to calculate the variable costs separately from the cost of production using the full costing method, the special orders stilt houses with a selling price of Rp 183.6 million is acceptable. Due to special order the sale price is greater than the variable costs incurred by the company in producing the stage.
\end{abstract}

Keywords: relevan cost, variable costing, full costing 


\section{PENDAHULUAN}

\section{Latar Belakang}

Pada prinsipnya suatu perusahaan yang didirikan oleh sekelompok orang yang dalam kegiatannya menghasilkan barang dan jasa memiliki tujuan yang sama, yaitu untuk mendapatkan laba yang maksimal dari sejumlah dana yang telah digunakan sebagai modal utama berdirinya perusahaan. Jumlah laba yang diperoleh menjadi indikator keberhasilan bagi perusahaan yang orientasinya mencari laba. Agar diperoleh laba sesuai yang dikehendaki, perusahaan perlu menyusun perencanaan yang baik. Hal tersebut ditentukan oleh kemampuan dari pihak manajemen dalam memprediksi kondisi dari usaha-usaha yang akan dilakukan pada masa yang akan datang yang penuh ketidakpastian, serta mengamati kemungkinan dari faktor-faktor yang dapat mempengaruhi laba untuk perusahaan tersebut.

Dalam menjalankan kegiatan suatu perusahaan, maka seringkali manajemen dihadapkan pada beberapa pilihan atau alternatif dari aktivitas yang dilakukan. Dari setiap alternatif yang ada, maka manajemen harus memilih salah satu alternatif yang dapat memberikan keuntungan yang besar bagi perusahaan. Untuk memilih salah satu dari alternatif tersebut, maka pihak manajemen membutuhkan informasi tentang biaya.

Informasi tentang biaya yang relevan menjadi hal yang penting yang senantiasa diperlukan oleh perusahaan dalam pengambilan keputusan yang tepat. Pengambilan keputusan pada hakikatnya merupakan pemilihan di antara serangkaian alternatif tindakan.

Salah satu yang menjadi faktor utama dari kegagalan yang dialami oleh suatu perusahaan adalah kesalahan dari pihak manajemen dalam mengambil keputusan. Setiap keputusan yang diambil oleh pihak manajemen akan menjadi tolak ukur keberhasilan dari suatu perusahaan di masa yang akan mendatang.

\section{Tujuan Penelitian}

Tujuan penelitian ini adalah:

a. Untuk mengetahui perhitungan biaya harga pokok produksi yang digunakan oleh perusahaan.

b. Untuk menganalisis biaya relevan dalam kaitannya dengan pengambilan keputusan atas menerima atau menolak pesanan khusus.

\section{TINJAUAN PUSTAKA}

\section{Konsep Akuntansi Manajemen}

Wild and Shaw. 2010:4, menyatakan "Managerial accounting is an activity that provides financial and nonfinancial information to an organization's managers and other internal decision makers". Akuntansi manajerial adalah kegiatan yang memberikan informasi keuangan dan non keuangan untuk manajer organisasi dan pengambil keputusan internal lainnya.

Atkinson et al. 2012:2, menyatakan "Management accounting is the process of supplying the managers and employees in an organization with relevant information, both financial and nonfinancial, for making decision, allocating resources, and monitoring, evaluating, and rewarding performance". Akuntansi manajemen adalah proses memasok informasi yang relevan kepada manajer dan tenaga kerja, baik informasi keuangan maupun non keuangan, untuk pengambilan keputusan, pengalokasian sumber daya, dan pemonitoran, pengevaluasian, dan pemberian imbalan terhadap kinerja.

Garrison (et al. 2008:2), menyatakan "Managerial accounting is concerned with providing information to managers-that is, people inside organization who direct and control its operation". Akuntansi manajerial berkaitan dengan pemberian informasi kepada manajer yaitu orang-orang dalam organisasi yang mengarahkan dan mengendalikan operasi.

\section{Perbedaan Antara Akuntansi Keuangan dan Akuntansi Manajemen}

Perbedaan antara akuntansi manajemen dan akuntansi keuangan mencuat karena kedua tipe akuntansi ini melayani pemakai informasi yang berlainan.

Simamora (2012:15) menyatakan hal-hal yang membedakan antara akuntansi keuangan dan akuntansi manajemen. 

a. Pemakai informasi
b. Frekuensi pelaporan
c. Skema klasifikasi
d. Orientasi waktu
e. Relevansi dan fleksibilitas data
f. Presisi informasi
g. Unit pelaporan
h. Sumber displin

\section{Penentuan Harga Pokok Produk}

Penentuan harga pokok produk yang konvensional adalah dengan membebankan semua unsur biaya produksi (biaya bahan baku, biaya tenaga kerja, dan biaya overhead pabrik) baik yang bersifat tetap maupun variabel kepada produk atau jasa. Metode tersebut dikenal dengan nama penentuan harga pokok penuh (full costing), atau sering pula disebut dengan metode absorption costing atau conventional costing.

Penentuan harga pokok variabel (variable costing) merupakan metode penentuan harga pokok produk yang membebankan unsur biaya produksi yang bersifat variabel saja. Unsur biaya produksi bersifat tetap diperlakukan bukan sebagai harga pokok produk melainkan sebagai unsur biaya periodik. Biaya periodik merupakan biaya yang lebih erat hubungannya dengan periode akuntansi daripada dengan produk yang dihasilkan dan umumnya biaya periodik bersifat tetap (Halim et al.2013:47).

\section{Perbedaan Antara Metode Full Costing dan Variable Costing}

Perbedaan antara metode full costing dan metode variable costing yang dikemukakan oleh (Halim et al. 2013:49) seperti diuraikan di bawah ini.

a. Berdasarkan perhitungan harga pokok produk tersebut di atas dapat dikatakan bahwa perbedaan antara kedua metode tersebut terletak pada perlakuan terhadap biaya overhead pabrik yang bersifat tetap.

1) Menurut Metode Full Costing.

Biaya overhead tetap diperhitungkan dalam harga pokok. Biaya overhead pabrik tetap belum diakui sebagai biaya sampai saat produk atau jasa yang bersangkutan terjual, karena biaya overhead pabrik tetap masih melekat pada persediaan produk atau jasa yang belum terjual.

2) Menurut Metode Variable Costing.

Biaya overhead pabrik diperlakukan sebagai biaya periodik. Variable costing memperlakukan biaya overhead pabrik sebagai biaya periodik, sehingga langsung diakui sebagai biaya pada saat terjadinya. Dengan kata lain, pengertian biaya periodik berbeda menurut masing-masing metode tersebut.

b. Jika biaya overhead pabrik dibebankan kepada produk atau jasa berdasarkan tarif yang ditentukan di muka dan jumlahnya berbeda dengan biaya overhead pabrik sesungguhnya maka selisihnya dapat berupa pembebanan overhead pabrik berlebih (overapplied factory overhead) atau pembebanan overhead pabrik kurang (underapplied factory overhead).

1) Menurut Metode Full Costing.

Selisih tersebut dapat diperlakukan sebagai penambah atau pengurang harga pokok produk yang belum laku dijual (harga pokok persediaan).

c. Penyajian laporan rugi-laba, terutama dasar yang digunakan dalam klasifikasi biaya.

1) Menurut Metode Full Costing.

Pada laporan rugi-laba metode full costing, biaya dikelompokkan berdasarkan fungsi pokok yang ada dalam perusahaan, yaitu fungsi produksi - fungsi pemasaran - fungsi administrasi dan umum. Pada perhitungan rugi-laba pada metode full costing digunakan istilah laba kotor (gross profit).

2) Menurut Metode Variable Costing.

Pada laporan rugi-laba metode variable costing, biaya digolongkan berdasarkan perilakunya terhadap perubahan volume atas kegiatan-kegiatan perusahaan. Pada perhitungan laporan rugi-laba metode variable costing dipergunakan istilah margin kontribusi, yaitu kelebihan hasil penjualan dari biaya-biaya variabel (Halim et al.2013:49).

\section{Pengertian Biaya}


Simamora (2012:40), menyatakan biaya adalah kas atau setara kas yang dikorbankan (dibayarkan) untuk barang atau jasa yang diharapkan memberikan manfaat (pendapatan) pada saat ini atau di masa depan bagi perusahaan.

Rayburn (1999:4), biaya adalah mengukur pengorbanan ekonomis yang dilakukan untuk mencapai tujuan organisasi. Untuk suatu produk, biaya menunjukkan ukuran moneter sumber daya yang digunakan, seperti bahan, tenaga kerja dan overhead. Untuk suatu jasa, biaya merupakan pengorbanan moneter yang dilakukan untuk menyediakan jasa.

Horngren, et al. (2008:31) bahwa: "Biaya merupakan sumber daya yang dikorbankan (sacrificed) atau dilepaskan (forgone) untuk mencapai tujuan tertentu.

\section{Pola Perilaku Biaya}

Sistem kalkulasi biaya (costing system) mencatat biaya sumber daya yang diperoleh seperti bahan, tenaga kerja, dan peralatan, serta menelusuri bagaimana sumber daya tersebut digunakan untuk menghasilkan dan menjual produk atau jasa. Dengan mencatat biaya sumber data yang diperoleh dan digunakan akan memungkinkan manajer melihat bagaimana biaya berperilaku.

Sebagian besar keputusan yang diambil oleh manajemen memerlukan informasi biaya yang didasarkan pada perilakunya. Besar-kecilnya biaya dipengaruhi oleh besar-kecilnya volume produksi atau volume penjualan. Oleh sebab itu perlu diketahui penggolongan biaya atas dasar perilakunya. Perilaku biaya adalah pola perubahan biaya dalam kaitannya dengan perubahan volume kegiatan atau aktivitas perusahaan (Halim et al.2013:21).

\section{Pengertian Biaya Relevan}

Manajemen dalam melaksanakan fungsi perencanaan, koordinasi dan pengendalian akan selalu dihadapkan pada masalah pemilihan alternatif tindakan. Dari rangkaian alternatif tindakan yang ada, manajemen harus mengambil keputusan alternatif tindakan yang mana yang akan dipilih. Ketepatan pilihan yang dilakukan manajemen besar pengaruhnya dalam pencapaian tujuan perusahaan secara berhasil guna dan berdayaguna.

Keputusan berlandaskan pada prediksi perbedaan kinerja mendatang pada setiap alternatif. Pada saat memilih di antara alternatif-alternatif yang berbeda, manajer sepatutnya hanya berkonsentrasi pada biaya dan pendapatan yang berbeda di antara alternatif-alternatif keputusan. Biaya yang tetap sama, terlepas dari apa pun alternatif yang dipilih, dianggap tidak relevan untuk pengambilan keputusan. Keputusan yang berbeda biasanya memerlukan data yang berlainan pula.

Ambarriani (2000:92), menyatakan biaya relevan mempunyai dua sifat: (a) berbeda untuk setiap pilihan keputusan, (b) akan terjadi pada saat yang akan datang.

Biaya relevan dipergunakan untuk pengambilan keputusan yang menyangkut pemilihan berbagai alternatif tindakan bagi pihak manajemen. Biaya relevan adalah biaya masa depan yang diperkirakan dan pendapatan yang relevan adalah pendapatan masa depan yang diharapkan, yang berbeda di antara alternatif tindakan yang sedang dipertimbangkan oleh seorang manajer (Horngren, et al. 2008:446).

Halim et al.(2013: 107), dalam pengambilan keputusan taktis atau khusus, pihak manajemen harus melewati beberapa proses untuk pengambilan keputusan.

a. Mengidentifikasi dan mendefinisikan masalah.

b. Mengidentifikasi alternatif solusi yang dianggap tidak layak.

c. Mengidentifikasi biaya dan manfaat yang terkait dengan masing-masing alternatif solusi yang layak.

Kelompokkan biaya dan manfaat dalam relevan dan tidak relevan, dan mengeluarkan yang tidak relevan dari pertimbangan.

d. Jumlahkan biaya dan manfaat relevan untuk masing-masing alternatif.

e. Menilai faktor kualitatif.

f. Pilihlah alternatif dengan manfaat (secara keseluruhan) yang paling besar.

\section{Aplikasi Biaya Relevan dalam Pengambilan Keputusan}

Hansen dan Mowen (2009:76), aplikasi biaya relevan dalam pengambilan keputusan adalah:

1. Keputusan Membuat Atau Membeli

2. Biaya Kesempatan

3. Keputusan Meneruskan Atau Menghentikan

4. Keputusan Pesanan Khusus 
5. Keputusan Menjual Atau Memproses Lebih Lanjut

Penelitian Terdahulu

Tabel 1 Penelitian Terdahulu

\begin{tabular}{|c|c|c|c|c|c|c|}
\hline $\begin{array}{l}\text { Nama } \\
\text { Peneliti/Tahun }\end{array}$ & Judul & Tujuan & $\begin{array}{l}\text { Metode } \\
\text { Penelitian }\end{array}$ & Hasil & Persamaan & Perbedaan \\
\hline Andry (2011) & $\begin{array}{l}\text { Analisis } \\
\text { Penerapan } \\
\text { Biaya Relevan } \\
\text { Dalam } \\
\text { Menerima } \\
\text { atau Menolak } \\
\text { Pesanan } \\
\text { Khusus pada } \\
\text { PT. Adinata di } \\
\text { Makassar. }\end{array}$ & $\begin{array}{l}\text { Untuk mengetahui } \\
\text { perhitungan biaya } \\
\text { relevan yang } \\
\text { dilakukan oleh } \\
\text { perusahaan dalam } \\
\text { menerima atau } \\
\text { menolak pesanan } \\
\text { khusus. }\end{array}$ & Deskriptif & $\begin{array}{l}\text { PT. Adinata } \\
\text { belum } \\
\text { melakukan } \\
\text { analisis biaya } \\
\text { relevan secara } \\
\text { tepat. }\end{array}$ & $\begin{array}{l}\text { Menganalisis } \\
\text { biaya relevan } \\
\text { dengan } \\
\text { kaitannya } \\
\text { dalam } \\
\text { pengambilan } \\
\text { keputusan } \\
\text { untuk } \\
\text { menerima atau } \\
\text { menolak } \\
\text { pesanan } \\
\text { khusus }\end{array}$ & $\begin{array}{l}\text { Metode } \\
\text { analisis yang } \\
\text { digunakan } \\
\text { peneliti } \\
\text { sebelumnya } \\
\text { menggunakan } \\
\text { metode regresi } \\
\text { kuadrat } \\
\text { terkecil. }\end{array}$ \\
\hline Geraldy (2012) & $\begin{array}{l}\text { Analisis Biaya } \\
\text { Relevan } \\
\text { Dalam } \\
\text { Pengambilan } \\
\text { Keputusan } \\
\text { Manajemen } \\
\text { Berkaitan } \\
\text { Dengan } \\
\text { Special Order } \\
\text { Pada PT Catur } \\
\text { Kreasi Aksara }\end{array}$ & $\begin{array}{l}\text { Untuk mengetahui } \\
\text { dampak yang } \\
\text { terjadi bila PT } \\
\text { Catur Kreasi } \\
\text { Aksara } \\
\text { menggunakan } \\
\text { metode biaya } \\
\text { relevan dalam } \\
\text { pengambilan } \\
\text { keputusan yang } \\
\text { berkaitan dengan } \\
\text { pesanan khusus } \\
\text { dari pelanggan } \\
\text { (special order). }\end{array}$ & Deskriptif & $\begin{array}{l}\text { Metode biaya } \\
\text { relevan } \\
\text { memegang } \\
\text { peranan penting } \\
\text { dalam } \\
\text { mengambil } \\
\text { keputusan } \\
\text { menerima atau } \\
\text { menolak } \\
\text { pesanan khusus. } \\
\text { Hanya biaya } \\
\text { relevan yang } \\
\text { diperhitungkan } \\
\text { dalam } \\
\text { penentuan harga } \\
\text { pokok produksi. }\end{array}$ & $\begin{array}{l}\text { Untuk } \\
\text { Menganalisis } \\
\text { biaya relevan } \\
\text { dengan } \\
\text { kaitannya } \\
\text { dalam } \\
\text { pengambilan } \\
\text { keputusan } \\
\text { untuk apakah } \\
\text { perusahaan } \\
\text { akan } \\
\text { menerima atau } \\
\text { menolak } \\
\text { pesanan } \\
\text { khusus }\end{array}$ & $\begin{array}{l}\text { Metode } \\
\text { analisis yang } \\
\text { digunakan } \\
\text { peneliti } \\
\text { sebelumnya } \\
\text { menggunakan } \\
\text { metode } \\
\text { margin } \\
\text { kontribusi. }\end{array}$ \\
\hline
\end{tabular}




\section{METODE PENELITIAN}

\section{Jenis Penelitian}

Jenis penelitian yang digunakan adalah metode penelitian kualitatif yang berlandaskan pada filsafat positivisme, metode penelitian ini digunakan untuk meneliti pada populasi atau sampel tertentu.

\section{Tempat dan Waktu Penelitian}

Tempat yang menjadi penelitian ini adalah CV. Manguni Perkasa yang berlokasi di Jl. Kakaskasen II No.

5. Kota Tomohon, Kecamatan Tomohon Utara.

\section{Prosedur Penelitian}

Prosedur penelitian yang dilakukan adalah sebagai berikut:

a. Survey objek penelitian.

b. Mengumpulkan data-data dari perusahaan serta melakukan wawancara.

c. Membandingkan dan mengolah setiap informasi yang di dapatkan secara langsung dan data-data pendukung dari setiap kegiatan/ aktivitas produksi CV. Manguni Perkasa

d. Mengolah data-data sesuai dengan dasar teori yang digunakan.

\section{Metode Pengumpulan Data \\ Jenis Data}

Jenis data yang digunakan dalam penelitan ini adalah data kuantitaif dan data kualitatif. Data kualitatif dalam penelitan ini yaitu data yang diperoleh dari dalam perusahaan yang bukan dalam bentuk angka, tetapi dalam bentuk lisan maupun tulisan, seperti sejarah singkat perusahaan, prosedur-prosedur perusahaan dan struktur organisasi perusahaan. Sedangkan data kuantitatif dalam penelitian ini yaitu data-data biaya harga jual, jumlah produksi, dan pendapatan perusahaan.

\section{Sumber Data}

Sumber data yang digunakan dalam penelitian ini adalah data primer dan data sekunder. Data primer dalam penelitian ini yaitu data yang diperoleh melalui pengamatan langsung dan wawancara dengan pimpinan dan karyawan perusahaan yang ada kaitannya dengan masalah yang diteliti. Sedangkan data sekunder adalah data yang diperoleh berupa formulir, dan dokumen lain yang berhubungan dengan masalah yang dibahas serta literatur yang dibaca dan dijadikan acuan oleh penulis.

\section{Teknik Pengumpulan Data}

Proses penelitian dan penulisan skripsi ini, penulis menggunakan metode pengumpulan data adalah sebagai berikut :

a. Observasi, yaitu pengumpulan data yang dilakukan dengan mengadakan pengamatan secara langsung ke obyek penelitian, tepatnya pada CV. Manguni Perkasa yang berada di Kota Tomohon, Sulawesi Utara.

b. Interview, yaitu bentuk pengumpulan data yang dilakukan dengan mengadakan wawancara atau tatap muka secara langsung dengan pimpinan perusahaan dan staf personil yang ada kaitannya dengan masalah yang akan dibahas.

c. Dokumentasi, yaitu penelitian yang dilakukan dengan jalan mengumpulkan dokumen-dokumen perusahaan yang ada kaitannya dengan masalah yang akan dibahas.

d. Tinjauan kepustakaan, Yaitu bentuk pengumpulan data yang dilakukan dengan mempelajari literaturliteratur, karya-karya ilmiah serta bacaan-bacaan lain yang berkaitan dengan penulisan.

\section{Metode Analisis Data}

Metode analisis yang digunakan dalam pembahasan skripsi ini adalah metode deskriptif. Metode ini membahas permasalahan yang sifatnya menguraikan, menggambarkan dan melukiskan suatu data atau keadaan sehingga dapat ditarik suatu kesimpulan untuk menjawab permasalahan yang ada. 


\section{HASIL PENELITIAN DAN PEMBAHASAN}

\section{Sejarah Singkat Harian Tribun Manado}

CV. Manguni Perkasa adalah salah satu dari sekian banyak perusahaan yang ada di Sulawesi Utara, khususnya di daerah Kota Tomohon. Produktivitas utama dari perusahaan ini adalah memproduksi rumah adat minahasa dari Sulawesi Utara. Perusahaan ini berlokasi di Jl. Kakaskasen Dua Lingkungan 5, TomohonSulawesi Utara. CV. Manguni Perkasa mulai terbentuk pada bulan Agustus tahun 1994 yang didirikan secara perorangan oleh Bapak Bart Senduk yang dikelola secara langsung beserta dengan istrinya, Ibu Milly Mosal.

\section{Visi dan Misi Harian CV. Manguni Perkasa}

Visi

"Teknologi Rumah Kayu Minahasa di tengah zaman modernisasi”.

\section{Misi}

Memperkenalkan Rumah Kayu Tradisional Minahasa sebagai salah satu warisan Budaya Minahasa dengan memanfaatkan teknologi inovatif.

\section{Hasil Penelitian}

\section{Harga Pokok Produksi}

CV. Manguni Perkasa menerapkan metode full costing dalam memperhitungkan harga pokok produksi disaat perusahaan memproduksi rumah panggung.

\section{Tabel 2 Biaya Bahan Baku}

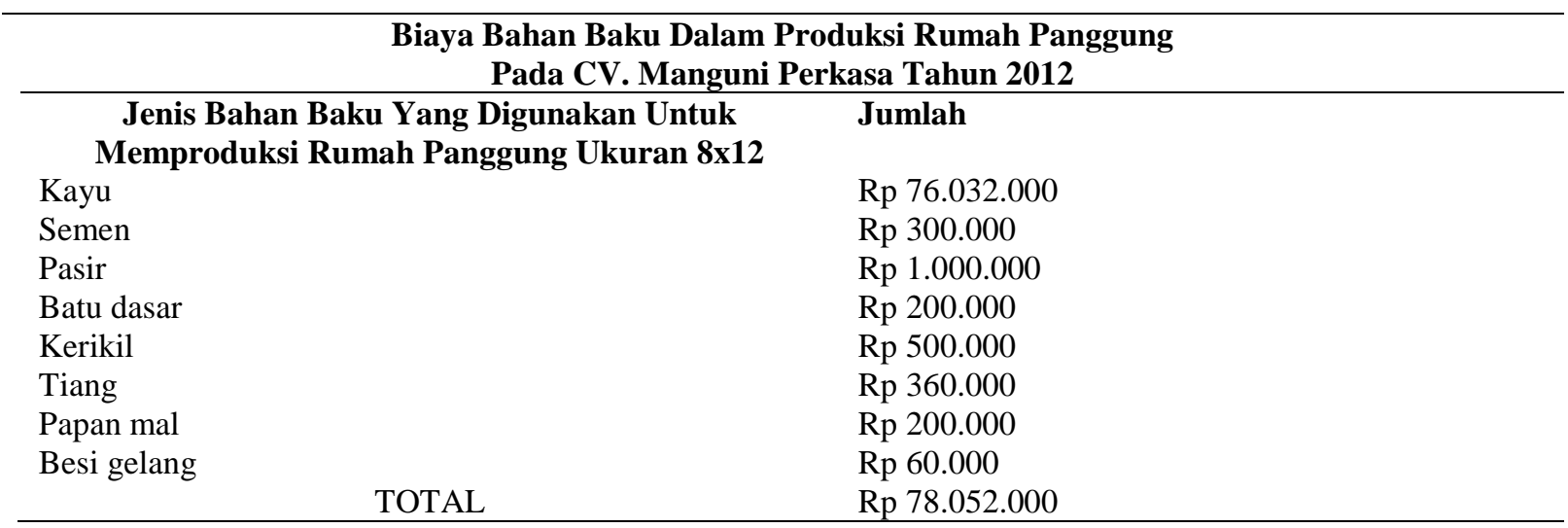

Sumber: CV. Manguni Perkasa (data diolah, 2013)

Tabel 3 Biaya Overhead Pabrik

\begin{tabular}{|c|c|}
\hline \multicolumn{2}{|c|}{$\begin{array}{c}\text { Biaya Overhead Pabrik Dalam Produksi Rumah Panggung } \\
\text { Pada CV. Manguni Perkasa Tahun } 2012\end{array}$} \\
\hline Biaya Overhead Pabrik & Jumlah \\
\hline Biaya tenaga kerja langsung & Rp 16.200 .000 \\
\hline Minyak dan oli mesin & Rp 3.240.000 \\
\hline Reparasi dan pemeliharaan mesin & Rp 3.240.000 \\
\hline Biaya jasa mesin & Rp 21.600.000 \\
\hline TOTAL & Rp 44.280.000 \\
\hline
\end{tabular}

Sumber: CV. Manguni Perkasa (data diolah, 2013)

\section{Pembahasan}


CV. Manguni Perkasa biasanya melakukan produksi normal dengan menghasilkan 10 rumah panggung dengan ukuran $8 \times 12$. Namun terdapat pesanan dari klien khusus yang memesan 5 unit rumah ukuran 8 x 12 dengan harga jual yang lebih rendah, yaitu sebesar Rp 183.600.000. Apabila dilihat hanya berdasarkan pada perhitungan harga pokok produksi full costing yang diterapkan oleh perusahaan, biaya produksi untuk satu unit rumah yang dikeluarkan oleh perusahaan sebesar $\mathrm{Rp}$ 182.226.900, maka dapat dikatakan bahwa perusahaan tidak akan mendapatkan keuntungan yang maksimal apabila perusahaan menerima pesanan khusus tersebut.

Penelitian ini bertujuan untuk menganalisis bagaimana peranan biaya relevan dalam kaitannya dengan pengambilan keputusan menerima atau menolak pesanan khusus, dengan kriteria apabila harga jual pesanan khusus lebih besar dari biaya variabel maka pesanan khusus tersebut dapat diterima, dan jika harga jual pesanan khusus lebih kecil dari biaya variabel maka sebaiknya perusahaan menolak pesanan khusus tersebut.

Berikut ini akan disajikan analisis penerapan biaya relevan berdasarkan data yang diperoleh.

Tabel 4 Perhitungan Harga Pokok Produksi Pada CV. Manguni Perkasa

\begin{tabular}{|c|c|c|}
\hline \multicolumn{3}{|c|}{$\begin{array}{c}\text { Perhitungan Harga Pokok Produksi Pada CV. Manguni Perkasa } \\
\text { Dalam Memproduksi Rumah Panggung } \\
\text { Menggunakan Metode Analisis Biaya Relevan (Relevan Cost) }\end{array}$} \\
\hline Nama Biaya & Real Cost & Relevan Cost \\
\hline \multicolumn{3}{|l|}{ Biaya bahan baku: } \\
\hline Kayu & Rp 76.032.000 & Rp 76.032.000 \\
\hline Semen & $\mathrm{Rp} 292.500$ & Rp 292.500 \\
\hline Pasir & Rp 240.000 & Rp 240.000 \\
\hline Kerikil & Rp 500.000 & Rp 500.000 \\
\hline Batu dasar & Rp 200.000 & $\operatorname{Rp} 200.000$ \\
\hline Tiang & Rp 360.000 & Rp 360.000 \\
\hline Papan mal & Rp 200.000 & $\operatorname{Rp} 200.000$ \\
\hline Besi gelang & Rp 60.000 & Rp 60.000 \\
\hline \multicolumn{3}{|l|}{ Biaya tenaga kerja langsung: } \\
\hline Upah buruh & Rp 16.200.000 & Rp 5.670.000 \\
\hline \multicolumn{3}{|l|}{ Biaya overhead pabrik: } \\
\hline Biaya tenaga kerja tidak langsung & Rp 9.000 .000 & Rp 3.150.000 \\
\hline Minyak & Rp 4.860.000 & Rp 4.860.000 \\
\hline Oli mesin & $\mathrm{Rp} 4.860 .000$ & $8=1.000 .000$ \\
\hline Biaya listrik & Rp 3.456.000 & Rp 3.456.000 \\
\hline Biaya telepon & Rp 864.000 & T \\
\hline Biaya jasa mesin & $\operatorname{Rp} 21.600 .000$ & - \\
\hline Biaya asuransi & $\operatorname{Rp} 2.160 .000$ & - \\
\hline Penyusutan gedung pabrik & Rp 2.160.000 & - \\
\hline Penyusutan mesin dan peralatan & Rp 1.080 .000 & - \\
\hline Reparasi dan pemeliharaan mesin & Rp 3.240 .000 & - \\
\hline Harga pokok produksi: & Rp 147.364 .500 & Rp 95.020.500 \\
\hline \multicolumn{3}{|l|}{ Biaya non-produksi } \\
\hline \multicolumn{3}{|l|}{ Biaya administrasi dan umum } \\
\hline Gaji karyawan adm. dan umum & $\operatorname{Rp} 25.920 .000$ & - \\
\hline Penyusutan gedung kantor & $\mathrm{Rp} 734.400$ & - \\
\hline P.B.B & Rp 432.000 & - \\
\hline \multicolumn{3}{|l|}{ Biaya pemasaran: } \\
\hline Gaji bagian pemasaran & Rp 7.776.000 & Rp 5.832.000 \\
\hline $\begin{array}{c}\text { TOTAL HARGA POKOK } \\
\text { PRODUKSI }\end{array}$ & Rp 182.226.900 & Rp 100.852.500 \\
\hline
\end{tabular}

Di dalam metode analisis biaya relevan, ada beberapa akun-akun biaya yang tidak perlu dihitung lagi misalnya biaya oli mesin, biaya telepon, biaya jasa mesin, biaya asuransi, penyusutan gedung pabrik, dan penyusutan mesin dan peralatan. Karena di dalam perhitungan harga pokok produksi yang digunakan oleh perusahaan adalah metode full costing, dimana dalam perhitungan full costing tersebut masih ada terdapat biaya tetap yang sebenarnya tidak akan mempengaruhi terhadap jumlah atau banyaknya produksi yang menjadi 
kegiatan rutin dari perusahaan. Biaya tersebut tetap ada meskipun perusahaan tidak melakukan produksi. Maka, biaya tetap tersebut tidak perlu diperhitungkan lagi.

Dengan jumlah biaya yang harus dikeluarkan oleh perusahaan dalam memproduksi rumah panggung ukuran 8x12 yaitu sebesar Rp 182.226.900 seperti yang dipaparkan dalam tabel 4 tidak akan memungkinkan bilamana perusahaan akan menerima pesanan khusus dari konsumen yang memesan 5 unit rumah panggung dengan harga yang lebih rendah sebesar Rp 183.600.000. Apabila dibandingkan dengan harga jual normal yang telah ditetapkan oleh perusahaan sebesar Rp 216.000.000, maka secara logika perusahaan akan menolak pesanan khusus tersebut karena perusahaan akan mengalami kerugian.

Namun jika dianalisis kembali dengan melihat perhitungan harga pokok produksi dengan menggunakan metode analisis biaya relevan (relevan cost) yang diterapkan dalam penelitian ini, ada beberapa akun-akun biaya yang tidak perlu diperhitungkan kembali (dihilangkan) seperti biaya pemakaian oli pada mesin, biaya telepon, biaya jasa mesin, biaya asuransi, penyusutan gedung pabrik, serta penyusutan mesin dan peralatan. Karena di dalam perhitungan harga pokok produksi yang digunakan oleh perusahaan adalah metode full costing, dimana dalam perhitungan full costing tersebut masih ada terdapat biaya-biaya tetap yang sebenarnya tidak akan mempengaruhi terhadap volume jumlah produksi perusahaan. Biaya tersebut tetap ada meskipun perusahaan tidak melakukan produksi. Maka, biaya tetap tersebut tidak perlu diperhitungkan.

Berdasarkan analisis dengan menggunakan metode biaya relevan (relevan cost) tersebut di atas, maka perusahaan hanya akan mengeluarkan biaya sebesar Rp 100.852.500 dalam memproduksi rumah panggung per unit. Dengan nilai total harga pokok produksi berdasarkan analisis biaya relevan yang telah diterapkan dalam penelitian ini, sebaiknya perusahaan menerima (mengerjakan) pesanan khusus yang diberikan oleh konsumen, karena perusahaan akan mendapatkan keuntungan yang maksimal bila menerima pesanan khusus tersebut.

Dengan meninjau kembali dari harga pesanan khusus yang ditawarkan oleh konsumen yaitu sebesar Rp 183.600.000, maka harga pesanan khusus tersebut ( $\mathrm{Rp} 183.600 .000$ ) jauh lebih besar daripada biaya variabel ( $\mathrm{Rp} 100.852 .500$ ) yang harus dikeluarkan oleh perusahaan dalam memproduksi rumah panggung. Dengan perhitungan yang ada maka perusahaan memperoleh keuntungan sebesar Rp 81.374 .400 untuk setiap penjualan satu unit rumah panggung ukuran $8 \times 12$ yang dijual dengan harga pesanan khusus tersebut.

\section{PENUTUP}

\section{Kesimpulan}

Dari hasil analisis dan pembahasan mengenai analisis perhitungan biaya relevan dalam pengambilan keputusan menerima atau menolak suatu pesanan khusus pada CV. Manguni Perkasa, maka dapat ditarik kesimpulan akhir dari penelitian ini adalah sebagai berikut.

1. Dalam perhitungan harga pokok produksi untuk menghasilkan satu unit rumah panggung dengan ukuran 8x12 yang diterapkan oleh CV. Manguni Perkasa adalah metode perhitungan full costing. Di setiap kegiatan produksi CV. Manguni Perkasa harus mengeluarkan biaya sebesar Rp 182.226.900. Apabila perusahaan menerapkan metode perhitungan yang baru dalam menghitung harga pokok produksi, yaitu analisis biaya relevan maka perusahaan hanya akan mengeluarkan biaya sebesar Rp 106.829.220 untuk memproduksi satu unit rumah panggung dengan ukuran $8 \times 12$.

2. CV. Manguni Perkasa menetapkan harga jual satu unit rumah panggung ukuran $8 \times 12$ dengan harga Rp 216.000.000. Pada tahun 2012, CV. Manguni Perkasa menerima pesanan konsumen dengan harga khusus yaitu Rp 183.600.000. Ditinjau dari harga pokok produksi dengan perhitungan metode full costing yang digunakan oleh perusahaan, maka perusahaan tidak akan menerima pesanan dengan harga jual khusus tersebut. Apabila perusahaan menerapkan analisis biaya relevan guna memperhitungkan harga pokok produksi maka perusahaan dapat menerima pesanan tersebut. Dengan menggunakan analisis biaya relevan, maka perusahaan tidak perlu menghitung kembali akun-akun biaya tetap yang sebenarnya akan selalu ada meskipun perusahaan tidak melakukan kegiatan produksi. Sehingga perusahaan dapat menerima (mengerjakan) pesanan khusus tersebut, karena harga jual pesanan khusus lebih tinggi ( $R p$ 183.600.000) bila dibandingkan dengan harga pokok produksi (Rp 100.852.500) yang harus dikeluarkan oleh perusahaan. 


\section{Saran}

Untuk menentukan harga pokok produksi dalam kegiatan produktivitas perusahaan melakukan perhitungan dengan metode full costing, tetapi perusahaan dapat memperhitungkan harga pokok produksi berkaitan dengan pengambilan keputusan untuk menerima atau menolak pesanan khusus dengan menggunakan analisis biaya relevan.

\section{DAFTAR PUSTAKA}

Anthony, A, Atkinson., Robert, S, Kaplan., Matsumura, Ella, Mae., Young, Mark, S. 2012. Management Accounting. $6^{\text {th }}$ Edition. Pearson Education, Inc. New Jersey.

Ambarriani, Susty. 2000. Manajemen Biaya. Buku I. Salemba Empat. Jakarta.

Garrison, H, Ray., Noreen, W, Eric., Brewer, C, Peter. 2008. Manajerial Accounting. Twelfth Edition. McGrawHill Irwin. New York.

Halim, Abdul., Supomo, Bambang., Kusufi, Muhammad. 2013. Akuntansi Manajemen (Akuntansi Manajerial). Edisi Kedua. Penerbit BPFE. Yogyakarta.

Hansen, Mowen, 2009. Akuntansi Manajerial. Buku II. Edisi 8. Penerbit Salemba. Jakarta.

Horngren, Datar, M., Foster, George. 2008. Akuntansi Biaya dengan Penekanan Manajerial. Jilid 1. Edisi Keduabelas. Penerbit Erlangga. Jakarta.

Rayburn, L, Gayle. 1999. Akuntansi Biaya dengan Menggunakan Pendekatan Manajemen Biaya Jilid 1. Edisi Keenam. Penerbit Erlangga. Jakarta.

Simamora, Henry. 2012. Akuntansi Manajemen. Edisi III. Star Gate Publisher. Duri, Riau.

Wild, John., Shaw, W. Ken. 2010 edition. Managerial Accounting.McGraw-Hill Irwin. New York. NY, 10020. 